\title{
Thermodynamic Assessment of the Copper-Lutetium Binary System
}

\author{
Said Kardellass ${ }^{1,2, *}$, Colette Servant ${ }^{3}$ and Hicham Gourgue ${ }^{2}$ \\ ${ }^{1}$ Laboratory of Thermodynamics and Energetics, Ibn-Zohr University, Morocco \\ ${ }^{2}$ Sustainable Innovation and Applied Research Laboratory, International University of Agadir, Morocco \\ ${ }^{3}$ Solid State Physicochemistry Laboratory, University Paris-Sud, France
}

*Corresponding author: Said Kardellass, Laboratory of Thermodynamics and Energetics, LTE, Ibn-Zohr University, Agadir, Morocco.

Submission: 㭗 June 20, 2018; Published: 㘹 June 26, 2018

\section{Opinion}

On the basis of lattice stabilities cited from Dinsdale [1], the optimization of the Copper-Lutetium binary system is carried out using the Thermo-calc software [2,3]. Thermo-calc software for evaluating the thermodynamic, kinetic and thermo-physical model parameters from experimental or theoretically calculated data by solving the weighted least squares problem. The phase diagram and thermochemical data were used as input to the program for the optimization. Each piece of selected information was given a certain weight by personal judgment and verified by trial and error method during the assessment until most of the selected experimental information was reproduced.

Up to 1988, no equilibrium diagram is available for CopperLutetium binary system then Subramanian \& Laughlin [4] determined the Copper-Lutetium equilibrium diagram from the extrapolated invariant temperatures of corresponding data for Copper-Lanthanide systems for which experimental phase diagrams are already known using the systematic methods described by Gschneidner \& Calderwood [5] in conjunction with thermodynamic considerations. At present the number of publications that represent original experimental information on the thermodynamic properties of Copper-Lutetium melts is close to 6 . The studied properties include the partial and integral mixing enthalpies of components [6-9] activity [10] of components and enthalpy of formation from $[11,12]$.

This work deals with an assessment of the thermodynamic description of the Copper-Lutetium binary system by means of the CALPHAD method. A set of self-consistent thermodynamic parameters of the Copper-Lutetium binary system was obtained.

\section{References}

1. Dinsdale AT (1991) SGTE data for pure elements. Calphad 15(4): 317425.

2. Jansson B (1984) PhD Thesis. Royal Institute of Technology Stockholm, Sweden.

3. Sundman B, Jansson B, Andersson JO (1985) The Thermo-Calc databank system. Calphad 9(2): 153-190.

4. Subramanian PR, Laughlin DE (1988) The Cu-Ho (Copper-Holmium) System. Bulletin of Alloy Phase Diagrams 9(3a): 359-363.

5. Gschneidner KA, Calderwood FW (1983) Use of systematics for the evaluation of rare-earth phase diagrams and crystallographic data. Bulletin of Alloy Phase Diagrams 4(2): 129-131.

6. Nikolaenko IV, Turchanin MA, Batalin GI (1988) Rasplavy 2(2): 127-128.

7. Fitznerand K, Kleppa OJ (1997) Thermochemistry of binary alloys of transition metals: The systems Me-Gd, Me-Ho, and $\mathrm{Me}-\mathrm{Lu}(\mathrm{Me}=\mathrm{Cu}, \mathrm{Ag}$, and $\mathrm{Au}$ ). Metal Mater Trans 28(1): 187-190.

8. Watanabe S, Kleppa OJ (1984) Thermochemistry of alloys of transition metals: Part IV. Alloys of copper with scandium, yttrium, lanthanum, andlutetium. Metall Trans 15(2): 357-368.

9. Turchanin MA (2011) Temperature-composition dependence of thermodynamic mixing functions of liquid alloys of copper with rareearthmetals. Powder Metallurgy and Metal Ceramics 50(7-8): 512-527.

10. Berezutskii VV, Lukashenko GM (1988) Thermodynamic properties of liquid copper-Lutetiuma lloys. Rasplavy 23: 115-116.

11. Kardellass S (2018) Calculator Miedema software. Personal Communication.

12. De Boer FR, Boom R, Mattens WCM, Miedema AR, Niessen AK (1989) Cohesion in metals, Elsevier, USA. 
(c) (i) Creative Commons Attribution 4.0 International License

For possible submissions Click Here

Submit Article

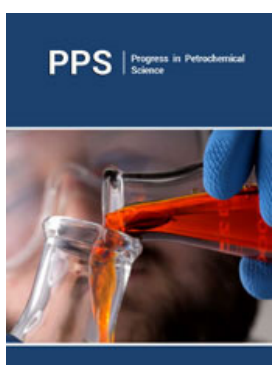

\section{Progress in Petrochemical Science}

Benefits of Publishing with us

- High-level peer review and editorial services

- Freely accessible online immediately upon publication

- Authors retain the copyright to their work

- Licensing it under a Creative Commons license

- Visibility through different online platforms 